\title{
立体映像コンテンツ制作環境の開発（2）
}

\author{
○柴田 隆史*、河合 隆史*、井上哲理**、坂口 裕介***、岡部 和重*** \\ (*早稲田大学、**神奈川工科大学、***レッッ・コーポレーション)
}

A development of a system for producing stereoscopic 3-D movies

Takashi Shibata', Takashi Kawai, Tetsuri Inoue“, Yusuke Sakaguchi”', Kazusige Okabe.*

('Waseda University, "Kanagawa Institute of Technology, '“Let's Corporation)

\section{1. 立体映像コンテンツ編集システムの開発}

本稿では、本研究で開発した立体映像コンテンッ 制作環境における、編集システムについて述べる。 1. 1 仕様の検討

本研究における編集システムでは、立体映像編集 に特有の機能として、以下の7種類を有するソフト ウエアの開発を行った。

（1）時分割の立体動画ファイルの分離機能

(2) 左右の動画像を時系列で表示する機能

（3）水平/垂直視差の補正機能

（4）画像サイズ/回転/歪みの補正機能

（5）立体像の再生位置の計算機能

（6）入カシステムと連動した自動補正機能

（7）時分割の立体動画ファイルの生成機能

なお、開発環境としては、Microsoft Visual Studio 6.0（Visual C++ 6.0）を選定した。

\section{2 プロトタイプの開発}

本システムのプログラミング作業と並行して、 ユーザインタフェースデザインの検討を行うため、 機能制限のある評価用のプロトタイプを開発した。

\section{3 プロトタイプの評価}

立体映像の編集経験を有する大学生および大学院 生10名を対象とし、プロトタイプのユーザビリティ テストを行った。本システムを用いた立体映像編集 の基本操作に関する6種類のタスクを与え、その遂 行状態とプロトコルについて分析を行った。結果か ら、時分割の立体動画ファイルの分離操作におい て、被験者の顕著なエラーが認められた。また、ユー ザへの情報呈示の点において、改善すべき問題点を 把握することができた。

\section{4 ユーザインタフェースの設計}

プロトタイプにおける問題点の改善として、用語 を変更し、操作の手順に沿ったレイアウトを検討し た。各UIパーツは、機能別に整理したデザインを構
築することで、操作性の向上を図った。例えばメイ ン画面では、ファイルの入出力や動画の時系列表 示、動画の編集といった指示部と操作部をマッピン グすることで、各部の関係が直感で分かるよう配慮 した。さらに、立体映像特有の編集を行う各画面に おいても、情報呈示の構造を統一した。

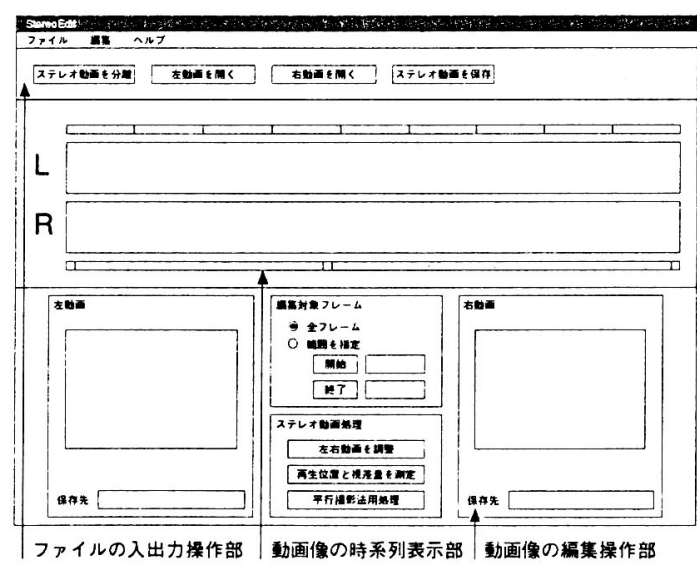

図1編集システムのメイン画面のUIデザイン

こうして開発した編集システムのメイン画面を図 2に、左右動画の処理画面を図3に示した。

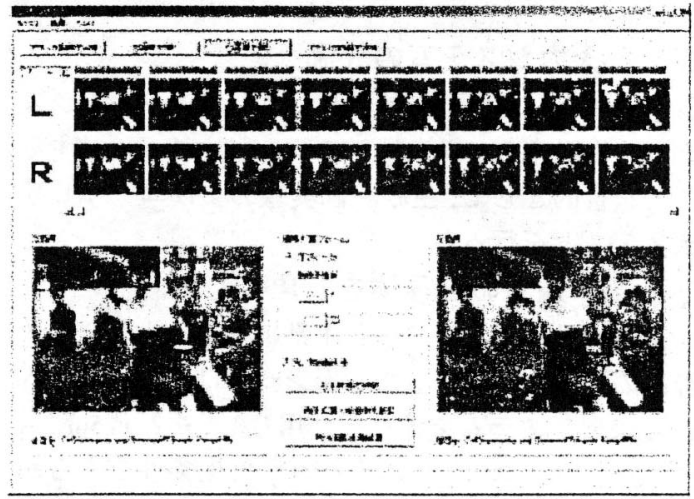

図2 編集システムのメイン画面 


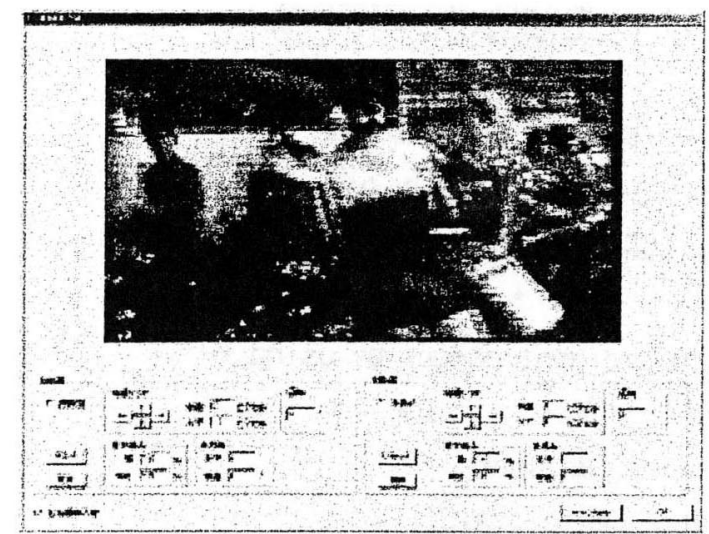

図3＼cjkstart左右動画の処理画面

表 1 編集システムの動作環境

\begin{tabular}{|l|l|}
\hline OS & Microsoft Windows(R) 98, 98SE, 2000 \\
\hline CPU & $\begin{array}{l}\text { Intel MMX Pentium 200MHz以上 } \\
\text { (PentiumIII 800MHz以上を推奖) }\end{array}$ \\
\hline メインメモリ & 128MB（256MB以上を推奖） \\
\hline $\begin{array}{l}\text { 対応動画 } \\
\text { ファイル }\end{array}$ & $\begin{array}{l}\text { 無圧縮AVIファイル } \\
\text { VCM集攵の圧縮AVIファイル }\end{array}$ \\
\hline
\end{tabular}

\section{2. 編集システムの評価}

立体映像の編集経験を有する大学生および大学院 生10名を対象とし、本システムのユーザビリティテ ストを行った。本システムに実装された各機能の操 作に関する8種類のタスクを与え、その遂行状態と プロトコルについて分析を行った。結果から、プロ トタイプの評価においてエラーが顕著であった、時 分割の立体動画ファイルの分離操作が円滑化された ことが認められた。しかしながら、時分割の立体動 画ファイルの分離と生成という、本システムの特有 の機能に戸惑う被験者もいたことから、メンタルモ デルに基づいたUIデザインの検討が課題としてあ げられた。その他の操作に関しては、比較的速やか に遂行され、インタビュー調査からもUIが改善され たことが確認された。

\section{3.まとめ}

本研究では、デジタルアーカイブを目的とした立 体映像コンテンツの制作環境の開発を行った。適用 領域をデジタルアーカイブに設定することで、適正 な立体情報の付加や質感の再現を重視すると同時 に、高速で移動する被写体などへの対応が不要とな ることから、入力/編集システムの簡易化を図っ た。具体的には、立体像の歪みの少ない平行法に
よって撮影された立体映像を、時分割方式で入力／ 編集するシステムを開発した。

入力システムでは、デジタルビデオカメラに付加 して立体映像に変換する、光学ユニットを開発し た。これを、編集システムと連動させることで、平 行法による簡易な撮影／再生が実現できた。評価実 験の結果から、従来型システムよりも使いやすいこ とが認められたが、立体感や見やすさの点で、従来 型システムを上回る評価を得ることはできなかっ た。この点については、立体映像の撮影条件の評価 方法の検討が、今後の課題点としてあげられた。さ らに、視覚状態の点においても、被写体に応じて撮 影条件を検討する必要性が示唆された。

編集システムでは、PCのハードディスクに取り 込まれた動画ファイルについて、立体映像編集に特 有の処理機能を有するソフトウエアを開発した。こ れにより、同期運転された4台のVTRが必要であっ た従来の方式と比較すると、大幅なシステムの簡略 化ができた。加えて、これまで困難であった時分割 立体映像の編集段階での補正が可能となった。ま た、開発段階からUIデザインを評価／検討したこと で、システムのユーザビリティを向上することがで きた。

さらに、本研究開発の成果を、今後の立体映像コ ンテンッの制作へ活用していくためには、以下の5 点が課題として残されている。

(1)入力システムの小型／軽量／低価格化

(2)入力システムの評価方法の検討

(3)編集システムのプレビュー機能の付加

(4)編集システムのUIデザインの改良

(5)コンテンツの伝送/再生システムの検討

\section{Acknowledgement}

本研究は、通信・放送機構の平成 11 年度「産学連 携支援·若手研究者支援型研究開発制度」に係石研 究開発課題である。 